This is a self-archived version of an original article. This version may differ from the original in pagination and typographic details.

Author(s): likkanen, Päivi

Title: Migrant women, work, and investment in language learning : Two success stories

Year: 2022

Version: Published version

Copyright: (C) 2019 Walter de Gruyter GmbH, Berlin/Boston

Rights: In Copyright

Rights url: http://rightsstatements.org/page/lnC/1.0/?language=en

Please cite the original version:

likkanen, P. (2022). Migrant women, work, and investment in language learning : Two success stories. Applied Linguistics Review, 13(4), 545-571. https://doi.org/10.1515/applirev-2019-0052 


\title{
Päivi likkanen*
}

\section{Migrant women, work, and investment in language learning: Two success stories}

https://doi.org/10.1515/applirev-2019-0052

\begin{abstract}
In the media, migrant mothers are often portrayed as uneducated, having trouble learning a new language, and preferring to stay at home rather than entering paid employment. This article offers a contrasting point of view as a result of examining how two migrant women narrativize their experiences of language learning and working-life-related integration during a three-year period. Specific attention is paid to how the women make sense of their language use over time, and how this may have contributed to their integration into working life and the wellbeing of their families. Interview data was analyzed using the short story analytical approach, focusing on both the content and the various scales of context portrayed in the stories. The analysis is informed theoretically by the concept of investment. The findings indicate that, first, English was used when interacting with members and institutions of the Finnish society, but gradually the use of English was replaced by an emerging Finnish proficiency. At first with the help of English and later, by deciding to invest in learning Finnish, both key participants managed to build new careers and meaningful lives for themselves and their families in a new environment.
\end{abstract}

Keywords: integration, investment, language learning, migrant, short story analysis

\section{Introduction}

Professional migrant women often have trouble entering the workforce in their new home country. Sometimes these difficulties can be attributed to their having only an emerging proficiency in the dominant language, but there are also

\footnotetext{
*Corresponding author: Päivi likkanen, Department of Language and Communication Studies, University of Jyväskylä, PO Box 35, Fl-40014, Jyväskylä, Central Finland, Finland, E-mail: paivi.i.iikkanen@jyu.fi

https://orcid.org/0000-0002-3769-3387
} 
several underlying factors affecting newcomers' opportunities to find suitable employment. Participation in society may be seriously affected by the social organization of the community in which the migrants live, or they may experience class dislocation, for example in terms of housing or social networks (Piller 2016). For highly educated migrant mothers this is especially problematic, as these so-called mothering networks often consist of fellow migrants (Piller 2016: 157) who might not share their interests in general or their aspirations related to working life in particular. Learning the local language is, undoubtedly, one of the keys to working life integration (Integration Act 2010). However, many integration programs concentrate heavily on basic language instruction and vocational education, simply with the aim of making "migrants economically more productive" (Pöyhönen et al. 2018: 493). As learning the language is not usually enough to ensure that migrant women find suitable employment, they often need to engage in various re-skilling strategies, the specifics of which are affected by their respective migratory circumstances (Vouyioukas and Liapi 2013). Often, previously acquired professional competence or occupational qualifications are not properly recognized either (Duchêne et al. 2013). These are all reasons why even highly educated professional migrant women often end up becoming homemakers instead of entering paid employment (Forsander 2002; Martikainen et al. 2012; Ministry of the Interior 2009; Piller 2016), although diverging trajectories, or success stories, also exist, as will be shown in the present study.

In this paper, I intend to show how the two focal participants narrativize their investment in language learning in terms of facilitating their future careers and the wellbeing of their families. The central concept of investment used in the analysis was originally developed by Bonny Norton (Norton Peirce 1995; Norton 2000, Norton 2013), and it refers to the effort learners put into language learning in the hope of increasing the value of their cultural capital and, thus, providing themselves with access to new resources (Norton 2013: 50). Since I have followed the participants longitudinally, a narrative approach was a useful tool for tracing their individual language learning experiences and professional development. This also resonates well with examining the participants' trajectories, since looking at individuals who diverge from typical trajectories of socialization enables us to "learn both about the individual's particularity and about the collective resources used to accomplish that particularity" (Wortham 2005: 97). In this paper, the following questions will be addressed: How have the participants' everyday language practices changed during a three-year period and how does investment in language learning show in their talk? And, How do the participants narrativize the role of language learning in their professional development? Methodologically, I have applied the clock task (Mäntylä et al. 2009; 
Satchwell 2005) that consisted of a picture of a clock on which the participants marked their daily language use, and the timeline approach (Tasker 2018), a visual representation of the participants' life events and language learning trajectories. These tools were used to facilitate the interviews and help the participants reflect on the changes that had taken place in their language use and on how their integration has proceeded over time. The short story approach (Barkhuizen 2016), in turn, is used as an analytical tool to shed light on the participants' complex relationship to language learning, and its role in shaping their future in a new home country.

\section{Migrant women and language learning: Investment and trajectories}

This study focuses on the individual learning experiences of migrants who have migrated voluntarily, e.g. because of marriage, work or studies. This focus arises, first of all, from the fact that most research on the integration and the language learning challenges of migrants has concentrated rather heavily on people with a refugee background (see e. g. Martikainen et al. 2012; Pokorn and Čibej 2018; Skilton-Sylvester 2002), often combined with low literacy skills. Secondly, little is known about skilled (female) migrants, specifically those with young children, as they often arrive through the family route instead of as labor migrants (Kofman 2012), thus making it more difficult to find out how they "develop strategies for their own careers and professional integration in the receiving country" (Kofman 2012: 65). Female migrants with small children may also have difficulty participating in highly structured and time-consuming language learning programs (e.g. Intke-Hernández 2015; Pöyhönen and Tarnanen 2015). As most women, nevertheless, assume principal responsibility for the successful settling in of other family members, which calls for extensive interaction with e.g. schools and health care personnel (Kilbride et al. 2009), problems may well arise. It is therefore very important that the voices of these individual learners should be heard.

In line with the social turn in language learning research (see e.g. Block 2003) and, in order to shed more light on how social context affects the learning process, Bonny Norton (2013) developed the so-called identity approach to second language acquisition. In her study, Norton (2013) introduces five women who moved to Canada for various reasons, such as hope for a better future or escape from communist rule. These women's differing circumstances greatly influence their opportunities to invest in language learning, which initially lead Norton to 
examine the role of identity and power relations in the process of learning a new language. Essentially, this approach relies on poststructuralist theories of language (Bakhtin 1981; Bourdieu 1977; Hall 1997; Weedon 1997) and sociocultural theories of learning (Wenger 1998; Lantolf 2000; Lantolf and Thorne 2006; Lantolf et al. 2018). The most important aim of Norton's approach is to study the individual language learner in the context of the wider social world. In other words, the identity approach examines language learning as a "complex social practice rather than [as] an abstract, internalized skill” (Norton 2013: 166). The core of Norton's (2013) argument lies in the fact that learners invest in learning a second language in order to acquire a wider range of symbolic and material resources. This increases the value of their cultural capital and provides them with new resources such as access to the target language community (Norton 2013: 50). A number of other studies have also made use of the concept of investment, mainly to shed light on individual learning experiences (Menard-Warwick 2009; SkiltonSylvester 2002), highlight the role of the language learning environment in the learning process (Strömmer 2017) or examine how identities are constructed in the process of language learning (Barkhuizen 2016).

The theory of investment has been further developed by Darvin and Norton (2015), where they situate investment at the intersection of identity, ideology and capital to account for modern technological advances such as increased transculturality and the development of mobile communication. In their paper, the concept of capital (Bourdieu 1986) is elaborated by introducing the three types of capital (or power): economic/material, cultural and social. In short, economic capital refers to material resources such as property and income, cultural capital to knowledge or educational credentials, and social capital to social networks and connections (Darvin and Norton 2015: 44). The challenge in the migration context is, however, that the value of one's capital may shift, as it travels through space and time, reflecting the larger sociocultural context (Darvin and Norton 2015: 44-45). This means that for example language proficiency or an educational degree that were attained and valued in one's country of origin, may be radically devalued in the new country of residence (Darvin and Norton 2015: 44-45), and, thus, may not be recognized as symbolic capital. Due to the fluctuating value of their capital, migrants are placed in a difficult position when entering the labor market, as they will rarely be able to find employment that matches their expertise and qualifications achieved in pre-migration settings.

In addition to paying more attention to the individual learner and the language learning context, time is another dimension that deserves more attention in the study of language learning. Studies in language socialization (see e. g. Duranti et al. 2012), for example, have used the concept of trajectory, 
"a connected series of events across which individuals come to participate in forms of life" (Wortham 2005: 95), to shed light on long-term language learning processes. Understanding ‘trajectories of socialization' (Räisänen 2013; Wortham 2005) usually requires taking into account multiple timescales, including local and wider social-historical perspectives (Lemke 2000). In fact, it is sometimes relevant to analyze a unique configuration of timescales in order to reach an understanding of an individual's unexpected trajectory (Wortham 2005: 101). All this makes the concept well suited for analyzing a longitudinal research process such as the present study.

In the present study, the concept of investment, together with those of capital and trajectories, will be used to examine how the two focal participants, Natalie and Katherina, narrate their language learning experiences during their journey towards achieving both personal and professional goals.

\section{Research design and the data}

\subsection{Research design and selection of participants}

This paper is based on a larger, longitudinal study in which I have followed eight research participants' integration trajectories over a three-year period. I first met these migrant parents in 2015 when, together with our children, we participated in a multicultural family café in a mid-sized Finnish town with a mainly Finnish-speaking population. After I had made preliminary observations during the group's activities, eight people from diverse backgrounds agreed to participate in the research. The prerequisites for participation were proficiency in English and being a rather recent (max. five years of residence) voluntary migrant to Finland. English language skills were considered necessary so that we would be able to communicate without an interpreter. Being relatively recent migrants to Finland meant that it would be possible to examine the participants' experiences in the initial stages of their integration into Finnish society. Voluntary migrants who are parents of small children are a very much underresearched group, as most research involving stay-at-home parents (or usually only mothers) tends to be about people with a refugee background (e. g. SkiltonSylvester 2002). For this paper, I chose to concentrate on two focal participants, Natalie and Katherina, because of considerable differences in their backgrounds, language learning environments and the reasons they gave for staying in Finland and learning Finnish. The participants will be introduced in more detail in Section 4. 


\subsection{Data collection, the clock task and the timeline approach}

The first interviews with the participants were conducted in 2015-2016. I had a semi-structured interview guide, which mainly dealt with personal background information, daily language encounters, and the participants' understanding of the concept of integration (see Iikkanen 2017 for more details). To help the participants report on their daily language use, they were given a clock task (adapted from Satchwell 2005; Mäntylä et al. 2009), a picture of a clock, on which they were asked to mark their daily language use (see Appendices A-D for more details). The clock tasks were then used as a basis for discussion where the participants talked about their language use in more detail, for example with whom and in which contexts they used each of the languages in their repertoire. For the second (2017- early 2018) and third (10/2018) set of interviews, I reviewed the transcripts of the previous interviews and made notes about things I wanted to follow up. As I already knew the participants better and wanted to make the interviews as casual as possible, I did not prepare a structured interview guide. My main interest was to find out how their integration trajectories had unfolded: whether they were studying or working and how their language skills had developed. The clock task was administered in both the first and the second interviews to elicit information about the participants' daily language use and to record both the potential changes in their language practices and how investment in language learning showed in their talk, all of which contributes to answering the first research question.

For the third interview, I had constructed timelines (adapted from Tasker 2018), which are visual representations consisting of the participants' life events and important language learning experiences collected in the two earlier interviews and combined with actual interview excerpts (see Appendix E for details). I had sent the timeline drafts to the participants in advance before the third interviews and had invited them to comment, but received only a few minor corrections. Using the timelines meant, however, that in the interviews, the participants had a heightened awareness and a more informed opportunity to reflect on their emerging language learning trajectories. The timelines helped to generate information on the second research question: how the participants narrativized the role of language learning in their professional development.

In total, the three interviews with Natalie lasted for 118 minutes and with Katherina for 211 minutes. They took place at the university or at local restaurants. All of the interviews were transcribed verbatim and anonymized to make the participants less recognizable. Natalie preferred to have the third interview in Finnish, but I have translated Excerpt 2, presented in the following, into English. Some repetition, affirmations and contemplation such as yeah, mhm, 
aha and ok have been left out to make the text more reader friendly. The 4 excerpts chosen for analysis in this paper were selected on the basis of attempting to answer the two research questions: (1) How have the participants' everyday language practices changed during a three-year period and how does investment in language learning show in their talk? And, (2) How do the participants narrativize the role of language learning in their professional development? In the excerpts presented below, brackets ( ) are used for anonymized text, English translations of Finnish words are given in square brackets [ ] and ... indicates an omission during which the participants talked at length about something that was not directly linked to the focus of this paper.

\subsection{The short story approach}

To interpret the interview data, I first compared the clock tasks and looked for passages where the participants talked about using different languages, how they had invested in language learning, and what kind of career aspirations they had. Then, I applied the short story approach (Barkhuizen 2016) to analyze extracts that best illustrated the changes in the participants' language practices that had taken place between the interviews and provided insights into how they had invested in language learning to achieve their personal and professional goals.

Methodologically, the short story approach is a form of narrative inquiry that pays specific attention to the content and context of stories, which in this case are excerpts from interviews. In terms of content, attention is paid to three different dimensions featured in the stories: who, where, and when. In the analysis, who refers to the characters in the story and to their relationships and positions relative to one another, where to the spatial dimension (where the action takes place), and when to the temporal dimension (past, present and future) (Barkhuizen 2016: 661). In practice, "the aim in the analysis is to work systematically through the short story text, line by line, and to identify all references, explicit and implicit, to each of the dimensions, focusing on one dimension at a time" (Barkhuizen 2016: 661).

In terms of context, there are three interconnected levels of story (or contextual spaces) which guide the researcher to consider more macro-level social structures, discourses and ideologies instead of focusing solely on the experiences of individuals (Barkhuizen 2016: 662-663). The first level, story (all small letters), deals with personal and intimate experiences, whereas the second level, Story (with a capital S), refers to a wider context, where individuals have less agency and power in decision-making. The third level, STORY (all capital letters), comprises societal structures or more general discourses. In the following, these three 
levels are thought to correspond to the family (story), the workplace and institutions, such as schools (Story), and to government bodies, society and general discourses on migration on a larger scale (STORY). Usually, the narrator of the story does not explicitly recognize these wider structures, which means that it is up to the researcher to make the connections (Barkhuizen 2016: 664). These terms (story, Story and STORY) will also be used in the next Section, as excerpts from the interviews are analyzed.

\section{Changes in everyday language practices and investment in learning Finnish}

As already mentioned in Section 3, I first got acquainted with Natalie and Katherina at a multicultural family café which I also frequented with my then 18-month-old son. Next, I will use the short story approach (Barkhuizen 2016) described above to shed light on how Natalie's daily language practices changed over three years and how she narrativizes her integration trajectory and reasons for investing (Norton 2013) in language learning. Katherina's case will be discussed in the following subsection, 4.2.

\subsection{Natalie: Her (extended) family and becoming an entrepreneur as pathways to goal-oriented language learning}

Natalie is now 29 years old. She comes originally from Vietnam, where she studied and worked before coming to Finland. She learned English at a branch of an American university and was initially planning to move to the United States. However, she had a friend already living in Finland, and this was one of the reasons why she chose Finland instead. She came to study nursing in 2013, and met her Finnish husband very soon thereafter. They got married and had a baby in 2014, after which she gave up her nursing studies. The family lives with Natalie's parents-in-law. I interviewed Natalie three times over the threeyear period and, during that time she transformed herself from a stay-at-home parent into an entrepreneur. To trace this trajectory and how it connects to investment in language learning, two interview extracts (one from the first and one from the third interview) will be analyzed using the short story approach (Barkhuizen 2016). The analysis is also supported by the clock task featuring Natalie's everyday language use at different points in time. The third interview was also facilitated by a timeline (Tasker 2018) constructed in advance. 
Our first interview took place at the home of Natalie's parents-in-law in November 2015, our second one at the university in September 2017, and the third at a restaurant in October 2018. When Natalie first talked about her language use, she felt she had easy access to information through English. She still used a lot of English with her husband, and referred to herself as being lazy for doing that. When Natalie's husband was working, she mostly talked to her daughter in Vietnamese and to her in-laws in Finnish. The clock task Natalie completed in the first interview (Appendix A) illustrates this reality. Already in the first interview, Natalie mentioned that her future plan was to quit nursing studies and start a company of her own. In Excerpt 1, she talks about her plans. In the excerpt, $\mathrm{N}$ stands for Natalie and $\mathrm{P}$ for the present author.

Excerpt 1, first interview with Natalie (N) (11/2015).

$1 \mathrm{~N}$ : yeah, well, this is little secretly but

2 we planning that after I go to school, I want to go to Finnish course,

3 I already asked, I already talked with my t-officer ${ }^{1}$

4 that we planning that they find a school, a (vocational school) for me

5 I want to

6 P: so you won't go back to nursing school?

$7 \mathrm{~N}$ : no, no (vocational school)

8 no I will not go back to nursing but I want something new

9 I want to go to (vocational) school to be, to learn to be,

10 not (job title) but some kind of, what is that, yeah

11 but I planning to have a little business in here

... ( $N$ talks about the type of business she has been planning to start)

$12 \mathrm{~N}$ : yeah, and, you know, let's see if I can make it with my husband

13 or somewhere, someone else, but I cannot do it alone

14 of course I need one partner

15 but let's see, because I need to go to Finnish course first

16 and after that go to (vocational) school

17 it take me around two year and two year, two year to three year

18 and after that (my daughter) is already three, four years old

19 this thing easier

20 P: yes, a lot easier

$21 \mathrm{~N}$ : and I can start to do my planning

... ( $N$ talks about the type of business she has been planning to start and reflects on potential competition)

$22 \mathrm{~N}$ : but something small, I have no too much money or something

1 An official at the employment agency. 
23 P: no big investments

$24 \mathrm{~N}$ : no, no, no, not for that big investment

25 no, something small, I like it

26 and then because I planning that if I have something small

27 I have more time with (my daughter)

$28 \mathrm{ok}$, money is important but my daughter is more important

29 so I don't want to spend time all day for work

30 I want to use, spend my time with her

31 P: very nice, I'm so happy to hear this

$32 \mathrm{~N}$ : yeah, I know that is

33 for this moment is quite hard to get a job in Finland, is

$34 \mathrm{P}$ : in many areas it is, yes

$35 \mathrm{~N}$ : I can say that, but of course I know is change for me in 'sairaanhoitaja' [nursing]

36 but I want just to do something new, I just, I dunno

37 I just feeling I'm not fit so much for work in nursing field

Who. Natalie, her daughter and her potential business partner are the main characters in the story. Natalie feels that she wants something new (lines 8 and 36) instead of continuing her nursing studies and she has decided that establishing a small business of her own would be an ideal solution (story; personal level). She has also understood that she needs a partner (Story; institutional and workplace level), but it is still unclear who this imaginary partner could be (lines 12-14).

When. At the time of the first interview, Natalie's daughter was one year old, and Natalie was still staying at home with her (story). Nevertheless, Natalie was very future-oriented and had already made a detailed long-term plan (story): first, she needed to complete the Finnish language studies included in the integration program (line 15). After that, she would be able to go to vocational school and start learning a new profession (line 16), which would, then, enable her to establish a company of her own.

Where. The interview took place at Natalie's parents-in-law's house with Natalie's daughter and husband present, and her mother-in-law serving us coffee. In other words, the situation was very intimate, and showed Natalie's strong commitment to her family (story). However, most of our talk was highly future-oriented. Natalie talked about what she was planning to do so that she could both enter the Finnish job market (Story) and dedicate more time to her daughter (story) (lines 26-30). Educational institutions are also prominent in the interview, as courses and schools are mentioned many times throughout the excerpt (Story). When considering the bigger picture (STORY, wider societal 
level), Natalie connected her plan to start a company to the current employment situation in Finland (line 33).

This interview shows that learning Finnish represents a double incentive for Natalie: in order to run her own business in the future, Natalie needs to learn Finnish (Story), and by investing in language learning, she is also investing in the opportunity to spend more time with her daughter (story). By becoming selfemployed, Natalie would also rid herself of the undesirable label of an unemployed immigrant seeking economic benefits, a label that featured so prominently in current immigration discourses in Finland (STORY).

By the second interview in 2017, Natalie was in the middle of the process described above. She had completed the language courses included in the integration program (Integration Act 2010) and was now taking part in vocational training, studying in Finnish. Because of attending vocational school in Finnish and her predominantly Finnish-speaking home environment, Natalie said that she now spoke Finnish all day long ('suomea koko päivän') (see the clock task in Appendix B). In fact, Natalie even wanted to have the interview in Finnish instead of English. The second interview also revealed that Natalie was now planning to start the business together with her husband, who had resigned from his former job and started to study in vocational school for a new profession, just like Natalie was doing. One month before the third interview, in the fall of 2018, the couple's dream came true: Natalie and her husband had just started working for their own company. Interestingly, at this stage, Natalie's language use again seemed quite different from what it had been before: the predominance of Finnish had been replaced by the multilingualism of an international workplace, as the following excerpt shows. In the excerpt, $\mathrm{N}$ refers to Natalie and $\mathrm{P}$ to the present author.

Excerpt 2, third interview (10/2018) with Natalie (N) (my translation from Finnish into English). ${ }^{2}$

1 P: so now you must, or you can, speak Vietnamese also during the day here 2 or do you speak Finnish?

$3 \mathrm{~N}$ : yeah, well, because (employee) the person from China is here

4 we speak here Finglish, like English and Finnish

5 and with (my husband) everybody needs to speak English with him

6 and then Finnish too

7 P: so three languages

$8 \mathrm{~N}$ : mixed up

9 P: in turns and mixed up

2 The original Finnish transcript can be found in Appendix F. 
$10 \mathrm{~N}$ : we advertise we have an international (workplace) here and 11 but it's ok, kind of funny

12 (my husband) learns a few words of Vietnamese

13 P: yeah, actually he just said that he kind of understands it already

$14 \mathrm{~N}$ : yeah, and then

15 yeah and then (the employee) now learns a little Finnish

16 and things like more and

17 it's more like, kind of funny, and although English is, kind of

$18 \mathrm{P}$ : everyone can speak it?

$19 \mathrm{~N}$ : everyone can

20 P: yeah, it's like a common language

21 but it's very good, if they can learn Finnish here then at the same time $22 \mathrm{~N}$ : yes

23 P: yeah, I just remember that when I had the clock picture

24 last time you wrote on it 'Finnish all day long'

$25 \mathrm{~N}$ : yeah, it was true at school, and now also at home

Who. The story features the staff members of the newly established company: Natalie, her husband and their three employees (Story). Natalie seems to be very proud of their international workplace, where three different languages (English, Vietnamese and Finnish) are spoken interchangeably (lines 1-10). Although two of the company's employees are Vietnamese, English is, nevertheless, the lingua franca, because everybody (including Natalie's husband and one of the employees, who comes from China) can speak it (lines 17-20). For Natalie, it seems to be very important that she has been able to hire people from her native Vietnam and a person whom she had befriended earlier during a Finnish course (Story), thus making a personal contribution to society by enhancing migrants' job opportunities (STORY).

When. Natalie and her husband had just opened their business a month before the third interview (story). At that time, their lives were extremely busy and the length of their working days barely allowed them time to sleep. Despite her fatigue, later in the interview Natalie still managed to look into the future and predicted that in the future they would surely have more time for planning, development work, and for having family time (story).

Where. Natalie and her husband spend their days at their newly established company (Story). Looking back to the second interview through the clock task takes Natalie back to vocational school, where she mostly needed to speak Finnish (lines 23-25). Interestingly, Finnish has now become the language that she tends to use at home instead of at work (line 25) (story). 
Through the short story approach, I have attempted to illustrate the changes in Natalie's language practices and her investment in language learning as she reconstructed her language proficiency and professional competence to fit the Finnish job market and becoming an entrepreneur. Comparing the different aspects of content, the dimensions of who, when and where in the two interview excerpts, shows how Natalie's focus has shifted from the home to the work place and (Story), furthermore, to making a personal contribution to the surrounding society (STORY). The changes in Natalie's language use, this time the shift in focus from Finnish to English and Vietnamese brought about by the international and multilingual workplace, are quite remarkable. Interestingly, the expanding context from home to the work sphere has had a reverse effect on Natalie's language use: at work, she now has more use for English and Vietnamese than for Finnish, which was so predominant during her vocational studies, whereas Finnish is now the language she uses for the most part only at home. Through her own example, Natalie is making a strong personal contribution to the immigration discourse, as instead of being a looked-down-upon, unemployed migrant (see Norton 2013: 153), she is now providing work and language learning opportunities for others. Thus, investing in language learning has really paid off for Natalie: in addition to increased language proficiency, she has also gained a more prestigious social position and an opportunity to promote migrant entrepreneurship.

\subsection{Katherina: Motherhood and better work opportunities as reasons for investing in language learning}

The other focal participant, Katherina, is now 44 years old and comes from Hungary. She has three MA degrees and, in addition to her first language, she speaks fluent German, English and Spanish. She attended school and university in Austria and was working there when she met her Hungarian husband. Her husband was working in Finland, which eventually resulted in Katherina following him in 2013. They now have two children, aged five and two. Initially, Katherina was very reluctant to move to Finland and did not like living here at all, as she felt isolated and missed her family and friends. Her work opportunities also seemed very limited. However, the desire to be with her husband and, after becoming a mother, the wellbeing and future prospects of their family won out when she and her husband weighed up their options about where to live. In the following, two excerpts are analyzed through the short story approach and in the light of information on her use of language provided by two clock tasks (first and second interviews) and a timeline (third interview) we can see how 
Katherina talks about the relationship between the wellbeing of her family, language learning, and work. The interviews took place at a local cafeteria and over lunch at two different informal restaurant settings.

Before meeting her husband and having children, Katherina had been very independent and had worked a lot. Everything changed, however, when she moved to Finland and discovered that in order to have any kind of a career, she would have to start all over again. At first, she had a very hard time adjusting to life in a strange place where she did not know anyone other than her husband. She missed her family, friends and life in a big city. Having a small baby and not knowing the local language also limited her options considerably. She had mostly English-speaking friends, spoke Hungarian with her husband, and used some Finnish when visiting different offices (see clock task in Appendix C). Despite all the hardships, Katherina had a very clear idea of why she wanted to stay in Finland, as Excerpt 3 shows.

Excerpt 3, first interview with Katherina (K) (1/2016).

$1 \mathrm{~K}$ : yeah, and that's a huge difference if you have a child

2 so earlier I was only caring for myself

3 so I, my choices were my choices

4 but now, the choices are our choices

5 and I'm also, of course I'm thinking about (my son)

6 what is beneficial for him and what is not

7 and Finland, and Finland is absolutely beneficial for him,

8 while the Austrian education system wouldn't have been that beneficial for him 9 nor the Hungarian, it would have been absolutely worst, or the worst thing 10 so it is very good that he probably will be educated here and

11 I come in second

12 so my preferences come behind (my son)

Who Katherina and her son are the main characters in the story. Here, Katherina explains how her priorities changed after she became a mother: now her son comes first (their second child had not yet been born) (story). As a consequence, even though she is not particularly happy to be living in Finland, she is willing to live there in order to invest in her son's education (lines 7-10) (Story).

When The story takes place in the present, as Katherina explains her reasons for choosing to live in Finland. She also refers to earlier periods in her life, when she was on her own, and how everything is different now that she has a child (1-6) (story). Now her main priority is to ensure the wellbeing of her son, which brings a very strong future orientation to the story (Story). 
Where The excerpt refers to Finland as a desirable place to live if one is looking for quality education for one's children (lines 5-7) (Story). Other countries, where Katherina has previously lived, gone to school and studied, are also mentioned (lines 8-9). While she would personally be glad to move to either Austria or Hungary (story), she feels that they are not suitable options for them right now due to their unsatisfactory education systems (STORY).

There is ample evidence in other studies (e. g. Norton 2013; Skilton-Sylvester 2002) that motherhood is a very powerful factor in parents' decision-making processes, and that parents often base their decisions on what is best for their children, even renouncing their own potential needs in the process (story). This excerpt shows that Katherina is willing to endure a less than satisfactory life in Finland because, in the long run, it seems to be the best investment for the future of her children. It is indeed widely acknowledged internationally that the Finnish education system is exceptionally good (see e. g. Ministry of Education and Culture n.d.), and education is one of the key factors in making Finland a desirable place to live (Story).

By the second interview, Katherina's emerging Finnish proficiency had helped her a great deal to overcome some of her initial reluctance about living in Finland. She no longer had so much use for English in her everyday life, as evidenced by the clock task from the second interview (Appendix D), and she used Finnish when interacting with daycare staff in the morning and afternoon. Just before the second interview, in January 2018, Katherina had started working for their own company, although she was unhappy with the actual work. Unfortunately, her professional options in Finland were limited, as she could not really utilize her former work experience due to the high level of Finnish language proficiency required. In time, however, Katherina's work responsibilities in the company increased, and when we had the third interview eight months later she seemed very happy with the current state of affairs. In fact the change, as illustrated in Excerpt 4, had been quite profound. In the excerpt, $\mathrm{K}$ refers to Katherina and $\mathrm{P}$ to the present author.

Excerpt 4, third interview with Katherina (K) (10/2018).

$1 \mathrm{~K}$ : and during the day I have

2 a lot of English, a lot of Hungarian, a lot of English

3 some Finnish, but, because I don't attend a Finnish course at the moment

4 but there's one thing which has started last month

5 yeah October, so this October, so this month

6 it's that I became 'ohjaaja' [instructor] in a group of Finnish beginners

7 because our company won a grant from (a funding body)

8 so we do, they had a grant for 
9 it's kind of an integration program for newcomers to Finland, and 10 so this is already something in my, in work life which is

$11 \mathrm{P}$ : yeah, that's wonderful

$12 \mathrm{~K}$ : in Finnish

13 yeah, actually is new, new projects in our

14 or in my work are really great

15 so I don't feel that I am, or in the beginning I felt I was doing just leftover things

16 at the moment I have so much to do and I'm working on my own

17 so, doing my own things

18 but, it's good

19 yeah, I wasn't so optimistic about it

20 but right now I'm really

21 I'm satisfied

Who Katherina is the main character in this story. After having spent time at home with her children, she finally has a job in which she can use her newly acquired Finnish skills in Finnish working life (Story) (lines 10-12).

When The excerpt orients to the past, the present and the future as Katherina compares her work situation with what it had been like eight months before, when we had the previous interview, and sees how much has changed since then (lines 13-21) (story). The contents of the work have also changed, allowing her more independence and more challenging tasks (Story). Finally, she is able to use her own language learning experiences to help other people striving towards the same goals (Story).

Where As the story deals with Katherina's work, it is located in Katherina's home office (story). The wider context of the story features the Finnish course she is teaching and the new projects in her work (lines 4-12) (Story), through which she has gained the access to Finnish working life she has so desperately sought (STORY).

Katherina's interview, and the changes in the who/when/where dimensions of the stories, demonstrates how her focus has shifted from the home towards working life. Comparing the two interview excerpts underlines the fact that after initially deciding to invest in language learning and a life in Finland for the sake of her family, Katherina has now finally been able to find something to do that is meaningful for herself as well (story). Expanding horizons in working life have made it possible for her to feel she is making a contribution to society (STORY). The key to this has been her investment in language learning, which she could add to all her earlier qualifications. 


\section{Analyzing integration trajectories and investment in language learning through the short story approach}

It is a widely held assumption that once migrants learn the language of their new home country, they will automatically find adequate employment (see e. g. Piller 2016). Unfortunately, this does not always happen, as migration may confine even highly educated professional women to the home sphere because of difficulties entering the workforce at the desired level (Piller 2016). This study has shown that even people with limited institutional language learning opportunities, such as parents of young children, may achieve a great deal on a professional level by investing in language learning. Kramsch (2013: 195) comments that investment "accentuates the role of human agency and identity in engaging with the task at hand, in accumulating economic and symbolic capital, in having stakes in the endeavour and in persevering in that endeavour." One of the advantages of this study is its longitudinal nature, which enabled analysis of "the unique configuration of timescales relevant to understanding an individual's unexpected trajectory” (Wortham 2005: 101). In this context, the unexpected can be understood, first, to mean that the two women in this study were not "typical" uneducated immigrant mothers often portrayed in the media, and they certainly did not conform to the role of a traditional stay-at-home mother as far as their career achievements during the study were concerned. Second, the trajectory perspective also makes it possible to take into account the resources (or capital) that adult learners bring with them and how they use these resources to make sense of new experiences (MenardWarwick 2009: 179; Wortham 2005: 97).

Through the short story approach, I have attempted to show how investment in language learning has been one of the key factors in facilitating integration into Finnish working life for both Natalie and Katherina. Using this approach has enabled me to study how investment in language learning connects to people (who), places (where) and time (when), reflecting the highly contextual and social nature of the language learning process. This is evidenced, first of all, by the changes in the participants' everyday language practices visualized by the clock tasks (Appendices A-D). Completing the task allowed the participants to reflect on their everyday language practices, and showed how their learning trajectories had evolved between the interviews. Through the discussions stimulated by the task, it became evident that knowing English had been crucial for the parents at the beginning of their stay in 
Finland - it had provided them with a window, albeit a somewhat limited one, to the new society. This highlights the importance of examining language learning processes in a longitudinal manner, making it easier to account for the existing resources, such as English proficiency, that migrants bring with them. Had Natalie and Katherina not known English at all, it would have been much more difficult and taken them a lot more time to proceed with their language learning and professional goals. The data generated by the clock tasks also shows clearly that the daily use of English declined at the same time with a developing Finnish proficiency. In Natalie's case, the process was, however, reversed when the new company was established and the international background of their staff made it necessary for her to go back to using English (and her native Vietnamese). Fortunately, she still has the opportunity to use Finnish at home. The visual nature of the timelines (Appendix E) used in the third interview made them a useful tool in helping the participants realize how far they had actually come in a relatively short time. When Natalie was looking at hers, she concluded "when I came here to study nursing, I would not have believed that, in five years, I will have my own business in Finland and a family".

When investing in language learning, both women were also investing in the future and the wellbeing of their families in the long run (cf. Norton 2013), which ties the who/when/where dimensions of the short story approach well together. Natalie's investment to provide a better life for her family may not be immediately evident: to get where she is now, she has had to be flexible about some of her initial principles. Her involvement in work is somewhat at odds with the fact that her main reason to become an entrepreneur was to be able to spend more time with her daughter. As for Katherina, in spite of her willingness to sacrifice her own professional aspirations for the wellbeing of her family, and her reservations about ever being able to have a satisfactory professional life in Finland, she has also managed to find work that inspires her and where she is able to share her knowledge and experience.

Also, both Natalie and Katherina are mothers, which, for many reasons, can be one of the driving forces behind women's efforts to learn a new language (see e.g. Menard-Warwick 2009; Skilton-Sylvester 2002). For Katherina, this aspect of the personal (story) level is more prominent, as she has had to put a lot of thought on the matter. For her, it would also have been possible to live in Austria or Hungary, both of them countries that would have had a lot more to offer on the professional (Story) level, but for the sake of her family, she chose Finland (story). For Natalie, the case is perhaps more simple, 
as she originally came to Finland to learn a new profession. Also, she is married to a Finn, which gives her more opportunities to use Finnish in her everyday life. Nevertheless, it seems that her primary reason for investing in language learning and vocational education is more strongly connected to increased professional opportunities, whereas for Katherina it has taken much longer to figure out how to fulfill her professional interests. Due to differing circumstances and personal histories affecting their opportunities to invest in language learning (see e. g. Menard-Warwick 2009: 179), it seems that the trajectories of these two women differ the most on the personal (story) and professional (Story) level.

When looking at the bigger picture, however, one of the most important aspects of investing so heavily in learning Finnish for both Natalie and Katherina has been the opportunity to make a difference in society on a wider scale through their contributions to working life (STORY). This means that, finally, their increased cultural and social capital achieved through education has been recognized as legitimate (Bourdieu 1986; Norton 2013), and, has thus, been transformed into symbolic capital showcased by their newly acquired more prestigious social positions as migrants who have found work and become entrepreneurs, which, in the end, means they are also gaining more economic capital. This makes their STORY scales coincide and demonstrates the difference increased cultural and social capital can make in individuals' lives, when they are recognized as symbolic capital. Furthermore, employment has had a significant effect on the women's self-esteem and, hence, on the wellbeing of the whole family in each case (Pöllänen and Davydova-Minguet. 2017).

\section{Conclusion}

The concept of investment has been criticized, for example for its application of financial terms to learning (Kramsch, afterword in Norton's 2013 edition), for Norton's failure to include recorded examples of actual interactions by her participants in the data (Block 2007), and for her not accounting for the changes in her participants' identities during the research (Price 1995). Despite the criticism, I still feel that through the concept of investment, combined with the longitudinal aspect and the short story approach, I have been able to shed light on Natalie and Katherina's language learning experiences and to show what profound effects investment in language learning, with its consequent better 
professional integration, has had on their lives overall. By investing in language learning, both women have clearly acquired new symbolic and material resources, such as emotional wellbeing, increased language proficiency, work, and a more prestigious social position, all of which lies at the heart of Norton's (2013) argument inspired by Bourdieu's (1986) theory on the recognition of symbolic capital. These stories also bear a close resemblance to some of those introduced in Norton's original study, particularly those of Katarina, Martina and Eva, who were also mothers.

The short story approach has allowed the examination of the participants' integration trajectories on different levels, including wider socio-historical structures and general discourses, and at different points in time. It has enabled me to illustrate how the participants' involvement with Finnish society evolved as their language proficiency developed and they acquired new professional skills. A study that failed to examine their integration trajectories on this broader timescale and did not use the narrative lens would not have been able to do justice to their stories. Encouraged by the findings, I intend to keep following the participants and look forward to learning how their personal and professional integration trajectories keep intertwining with investment in language learning in the future.

As for the wider implications of this study, it highlights the importance of paying more attention to the longitudinal aspects of language learning, if one wishes to dig deeper into the social aspects and the situational nature of individual language learning experiences, thus making a contribution to a call articulated e. g. by Norton (2013: 15). This study also shows how important English proficiency can be to get a "head start" with personal and professional networking in Finland, because it allows people to be a lot more proactive and independent in their search for information on different kinds of activities and educational opportunities. Natalie' and Katherina's stories send a clear message to policy makers and government officials: professional migrant mothers are highly invested in language learning and in pursuing meaningful professional lives. Thus, it is certainly worthwhile to provide them with suitable learning and employment opportunities (cf. Adamuti-Trache et al. 2018). Community work lies in a key position in assisting migrant mothers to build new personal and professional networks in their attempt to "make life normal again” (Norton 2013: 128). 


\section{Appendix}

\section{A The clock task Natalie completed in the first interview (11/2015)}
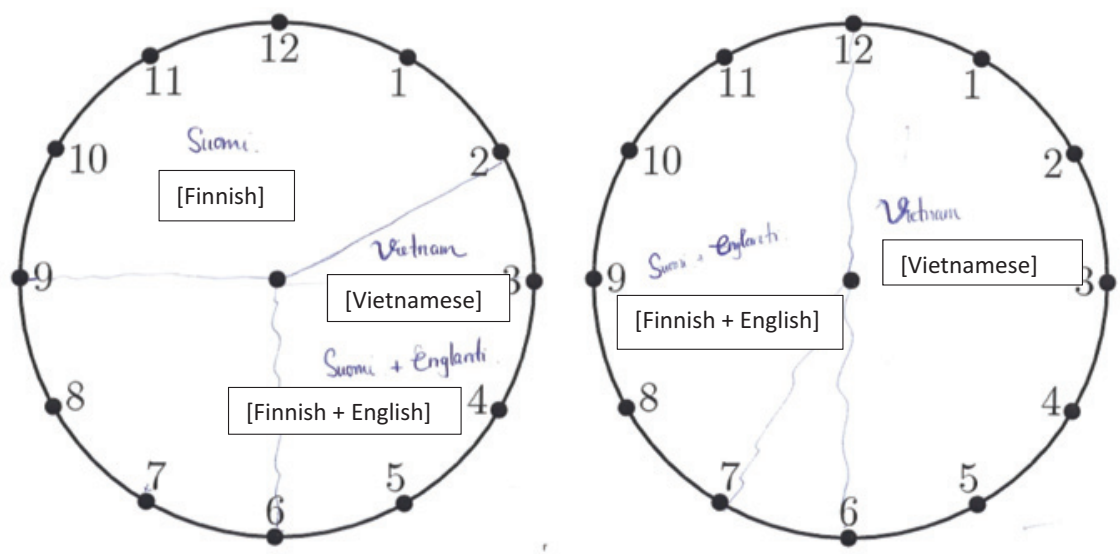

Which languages do you use at what time and with whom? Mark you daily language
eneountervlangage use on the clock. This clock is for the hours between 07.18.

Use this clock for the hours berween $19-06$

\section{B The clock task Natalie completed in the second interview (9/2017)}

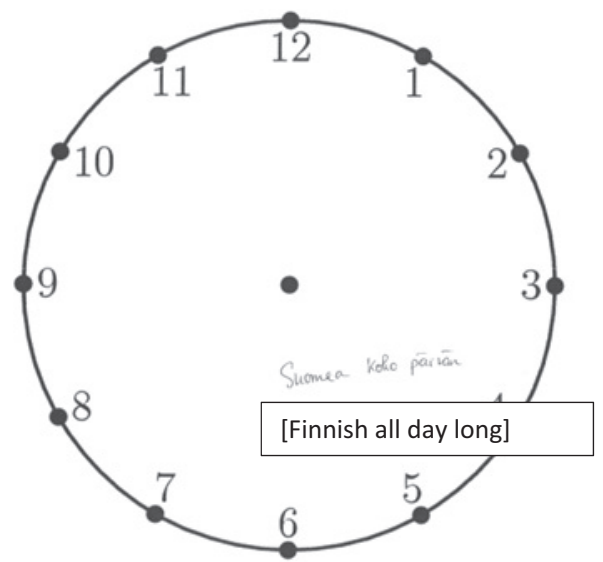

Which langages do you use at what time and with whore Mark you daily language 


\section{The clock task Katherina completed in the first interview $(1 / 2016)$}

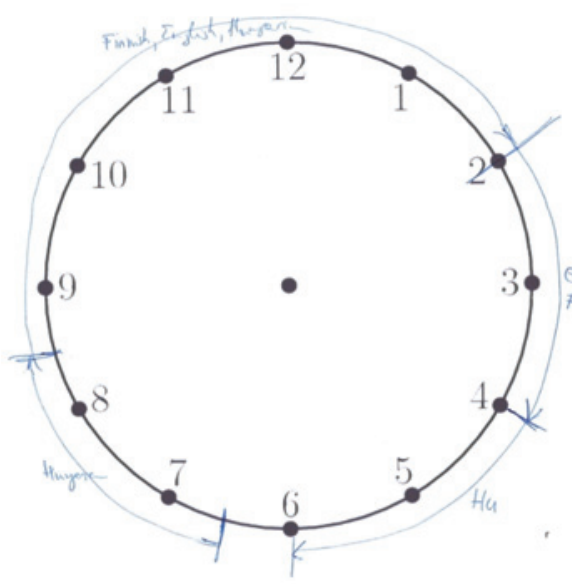

Which languages do you use $x$ what time and with whem? Mark you daily laspuage

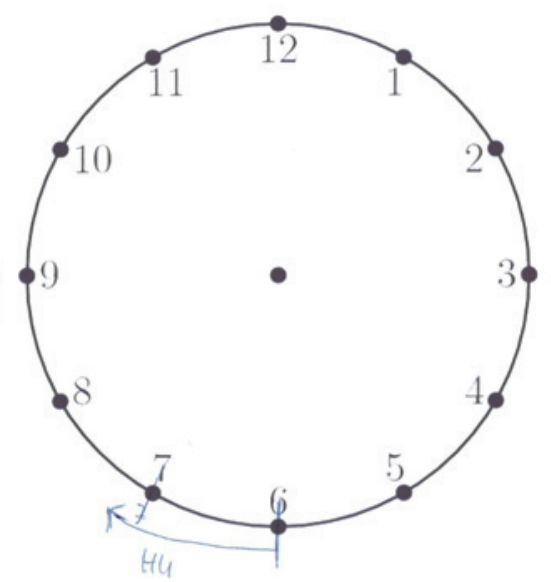

Use this dock for the bours between $19-06$

\section{The clock task Katherina completed in the second interview $(2 / 2018)$}
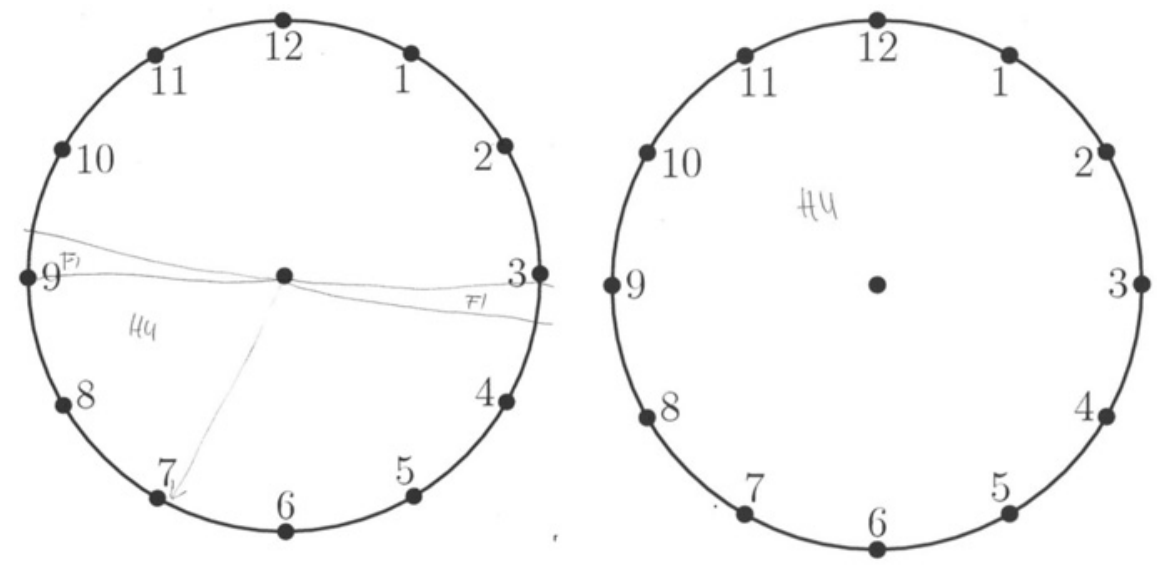

Which langanges do you use at whet time and with whom? Mark you deily language

Use this clock for the hours between 19-07. 


\section{E Katherina's timeline for the third interview (2018)}

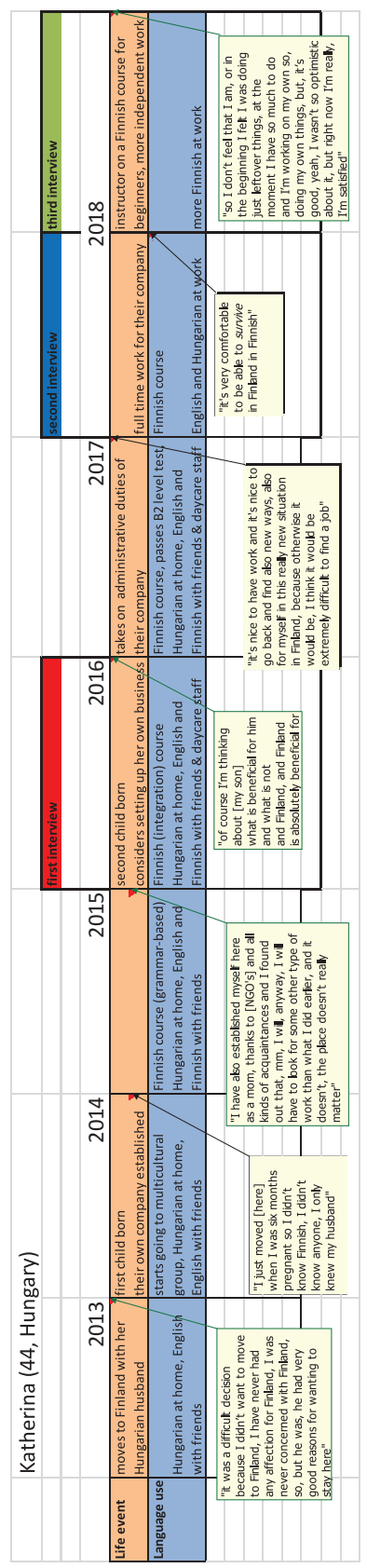




\section{F Excerpt 2: original interview with Natalie}

1 P: elikkä nyt sä joudut, joudut, tai voit, puhua vietnamia sitte päivälläkin täällä

2 vai puhutteko te suomea?

$3 \mathrm{~N}$ : joo, no, koska, [työntekijä], se kiinalaine on tässä

4 me puhutaankin täällä Finglish, niin kuin English ja suomi

5 ja se [aviomies] kanssa kaikki pitää puhua englantia

6 ja sitten suomea

7 P: mm, eli kolmea kieltä

$8 \mathrm{~N}$ : sekaisin

9 P: vuorotellen ja sekaisin

$10 \mathrm{~N}$ : me mainostetaan international [workplace] tässä ja

11 mutta ei se haittaa, aika hauska

12 [aviomies] oppii muutama vietnamia sanoja

13 P: nii, itse asiassa se sano äsken, että hän niinku ymmärtää sitä jo

$14 \mathrm{~N}$ : nii, ja sitten

15 nii, nii ja sitten se [työntekijä] nyt vähän niinkun oppia suomen kieli

16 ja jotain niinko lisää ja

17 se enemmän ja semmosta se aika hauska, ja vaikka englanti on niinkun, sitä

18 P: kaikki osaa sitä?

$19 \mathrm{~N}$ : kaikki osaa

20 P: joo, se on niinku yhteinen kieli

21 P: mut se on kyllä hyvä juttu, jos pystyy oppimaan suomee tässä sitte heki samalla

$22 \mathrm{~N}$ : kyllä

23 P: joo, muistan vaan, ku mulla oli niitä kellotaulukuvia

24 P: niin sä kirjotit siihev viimeksi, että suomea koko päivän

$25 \mathrm{~N}$ : nii, joo, totta se on koulussa ja nytkin kotona

\section{References}

Adamuti-Trache, Maria, Paul Anisef \& Robert Sweet. 2018. Differences in language proficiency and learning strategies among immigrant women to Canada. Journal of Language, Identity \& Education 17(1). 16-33. doi:10.1080/15348458.2017.1390433.

Bakhtin, Mihail. 1981. The dialogic imagination: Four essays. Austin: University of Texas Press.

Barkhuizen, Gary. 2016. A short story approach to analyzing teacher (imagined) identities over time. TESOL Quarterly 50(3). 655-668. 
Block, David. 2003. The social turn in second language acquisition. Edinburgh: Edinburgh University Press.

Block, David. 2007. The rise of identity in SLA research, post Firth and Wagner (1997). The Modern Language Journal 91. 863-876.

Bourdieu, Pierre. 1977. Outline of a theory of practice. Cambridge: Cambridge University Press.

Bourdieu, Pierre. 1986. The forms of capital. In J. G. Richardson (ed.), Handbook of theory and research for the sociology of education, 241-258. New York: Greenwood Press.

Darvin, Ron \& Bonny Norton. 2015. Identity and a model of investment in applied linguistics. Annual Review of Applied Linguistics 35. 36-56.

Duchêne, Alexándre, Melissa G. Moyer \& Celia Roberts. 2013. Language, migration and social inequalities: A critical sociolinguistic perspective on institutions and work. Bristol: Multilingual Matters.

Duranti, Alessandro, Elinor Ochs \& Bambi B. Schieffelin (eds). 2012. The handbook of language socialization. Malden: Wiley-Blackwell.

Forsander, Annika. 2002. Luottamuksen ehdot: Maahanmuuttajat 1990-luvun suomalaisilla työmarkkinoilla. [Conditions of trust: Immigrants in the 1990s Finnish labor market] Helsinki: Väestöliitto.

Hall, Joan Kelly. 1997. A consideration of SLA as a theory of practice: A response to Firth and Wagner. Modern Language Journal 81(3). 537-558.

likkanen, Päivi. 2017. The use of language in migrant stay-at-home parents' process of integration: Experiences of inclusion and exclusion. Apples - the Journal of Applied Language Studies 11(3). 121-142.

Integration Act. 2010. Act on the Promotion of Immigrant Integration (1386/2010). Ministry of the Interior, Finland. Unofficial translation.

Intke-Hernández, Minna. 2015. Stay-at-home mothers learning Finnish. In James Simpson \& Anne Whiteside (eds.), Adult language education and migration. Challenging agendas in policy and practice, 119-127. New York: Routledge.

Kilbride, Kenise Murphy, Vappu Tyyska, Rachel Berman, Mehrunnisa Ali, Isaac Woungang, Sepali Guruge, Susanna Edwards \& Robert Cazzola. 2009. Reclaiming voice: Challenges and opportunities for immigrant women learning English. Ottawa: Canadian Council on Learning.

Kofman, Eleonore. 2012. Gender and skilled migration in Europe. Cuadernos de Relaciones Laborales 30(1). 63-89. Retrieved from http://dx.doi.org.10.5209/rev_CRLA.2012.v30.n1. 39115. (accessed 14 April 2019).

Kramsch, Claire. 2013. Afterword. In Bonny Norton (ed.), Identity and language learning. Extending the conversation, 192-201. Bristol: Multilingual Matters.

Lantolf, James P. 2000. Sociocultural theory and second language learning. Oxford: Oxford University Press.

Lantolf, James P., Matthew E. Poehner \& Merrill Swain. 2018. The Routledge handbook of sociocultural theory and second language development. New York: Routledge.

Lantolf, James P. \& Steven L. Thorne. 2006. Sociocultural theory and the genesis of second language development. Oxford: Oxford University Press.

Lemke, Jay L. 2000. Across the scales of time: Artifacts, activities, and meanings in ecosocial systems. Mind, Culture, and Activity 7(4). 273-290.

Mäntylä, Katja, Sari Pietikäinen \& Hannele Dufva. 2009. Kieliä kellon ympäri: perhe monikielisyyden tutkimuksen kohteena [Languages around the clock: Family as a target of research in the study of multilingualism]. Puhe ja kieli 29(1). 27-37. 
Martikainen, Tuomas, Kathleen Valtonen \& Östen Wahlbeck. 2012. The social integration of immigrants in Finland. In James Frideres \& John Biles (eds.), International perspectives: Integration and inclusion, 127-146. Kingston: School of Policy Studies, Queen's University.

Menard-Warwick, Julia. 2009. Gendered identities and immigrant language learning. Bristol: Multilingual Matters.

Ministry of Education and Culture. n.d. Finland and Pisa. Retrieved from https://minedu.fi/en/ pisa-en. (accessed 12 November 2018).

Ministry of the Interior. 2009. Maahanmuuttajien työllistyminen ja kannustinloukut. [Employment of immigrants and inactivity traps]. Helsinki: Ministry of the Interior. Retrieved from https://www.hel.fi/static/helsinki/paatosasiakirjat/Kh2009/Esityslista17/ Liitteet/Maahanmuuttajien_tyollistyminen_ja_kannustinloukut_-selvitys.pdf?Action= sd\&id=\{E5AE45A6-C0B8-4919-A75A-A9AB08201106\} (accessed 17 December 2018).

Norton, Bonny. 2000. Identity and language learning: Gender, ethnicity and educational change. Essex: Longman.

Norton, Bonny. 2013. Identity and language learning: Extending the conversation, 2nd edn. Bristol: Multilingual Matters.

Norton Peirce, Bonny. 1995. Social identity, investment, and language learning. TESOL Quarterly 29(1). 9-31.

Piller, Ingrid. 2016. Linguistic diversity and social justice: An introduction to applied sociolinguistics. New York: Oxford University Press.

Pokorn, Nike K. \& Jaka Čibej. 2018. Do I want to learn a language spoken by two million people? Mediation choices by mid-term and long-term migrants. Language Problems and Language Planning 42(3). 308-327.

Pöllänen, Pirjo \& Olga Davydova-Minguet. 2017. Welfare, work and migration from a gender perspective: Back to 'family settings'? Nordic Journal of Migration Research 7(4). 205-213.

Pöyhönen, Sari \& Mirja Tarnanen. 2015. Integration policies and adult second language learning Finland. In J. Simpson \& A. Whiteside (eds.), Adult language education and migration. Challenging agendas in policy and practice, 107-118. New York: Routledge.

Pöyhönen, Sari, Mirja Tarnanen \& James Simpson. 2018. Adult migrant language education in a diversifying world. In Angela Creese \& Adrian Blackledge (eds.), The Routledge handbook of language and superdiversity, 488-503. Abingdon: Routledge.

Price, Stephen. 1995. Comments on Bonny Norton Peirce's 'Social identity, investment and language learning.' TESOL Quarterly 29(2). 331-336.

Räisänen, Tiina. 2013. Professional communicative repertoires and trajectories of socialization into global working life. Jyväskylä: University of Jyväskylä dissertation.

Satchwell, Candice. 2005. Literacy around the clock: an examination of the clock activity. Proceedings of 3rd International Conference - What a difference a pedagogy makes: researching lifelong learning \& teaching conference. Centre for Research in Lifelong Learning.

Skilton-Sylvester, Ellen. 2002. Should I stay or should I go? Investigating Cambodian women's participation and investment in adult ESL programs. Adult Education Quarterly 53(1). 9-26.

Strömmer, Maiju. 2017. Work-related language learning trajectories of migrant cleaners in Finland. Apples: Journal of Applied Language Studies 11(4). 137-160.

Tasker, Isabel. 2018. Timeline analysis of complex language learning trajectories: Data visualisation as conceptual tool and method. Applied Linguistics Review 9(2-3). 449-473.

Vouyioukas, Anna \& Maria Liapi. 2013. Coping with deskilling: strategies of migrant women across European societies. In Floya Anthias, Maria Kontos \& Mirjana Morokvasic-Müller 
(eds.), Paradoxes of integration: Female Migrants in Europe. International perspectives on Migration, 79-96. Dordrecht: Springer.

Weedon, Chris. 1997. Feminist practice and poststructuralist theory, 2nd edn. Oxford: Blackwell. Wenger, Etienne. 1998. Communities of practice: Learning, meaning, and identity. Cambridge: Cambridge University Press.

Wortham, Stanton. 2005. Socialization beyond the speech event. Journal of Linguistic Anthropology 5(1). 95-112. Retrieved from. http://repository.upenn.edu/gse_pubs/48. 